\title{
she leaves her mouth on things
}

\author{
kim dawn
}

\begin{abstract}
Avec "elle laisse sa bouche sur les choses," kim dawn utilise la répétition, la disposition, la sonorité des mots pour recréer leurs significations. Le O qui se répète $(\mathrm{OOOOO})$ ressemble à la bouche ouverte du sujet. Le O nous rappelle aussi la nullité, l'annihilation qu' "elle," le personnage, veut accomplir pour elle-même: "elle est là. rêvant d'un beau néant."
\end{abstract}

those. women. they

the fleshy baroque

womenO000000000000000000000000000000000000 00000000000000000000.

(she wants to put her little faces in all the folds and crevices of the fleshy mounds not like the decrepit girls who want to disappear look starved decrepit

(dreaming of fleshy mounds)

( to swim.

in)

shesdreamingofalltheprettyprettynoosesshecouldbuild

she leaves her mouth on things

she sees can't close eyes she sees her

face smashing against

anything face becoming all bloody like smashing face making pretty bloody

these impulses, it's an internal violence, it hurts no one but her her sacred bluey trembles but then there are blueys so sad she can't look at mom's eyes. she sees she (non)desires these thrashings to her own body banging her head upon the wall smashing her face against the floor and oh it's never just once it's over and over and over and over and 
over and 123 and 123 and 123 and 123 and 123 and 123 and 123 and 123 and 123 and 123 and 123 and 123 and

and it's a pretty hospital inside her head)

she leaves her mouth on things

she's there's a white pretty set so nicely sees in flashes her chin upon skidding upon ice her knuckles upon brick her face held under her mouth her face banging smashing and then the mounds of fleshy

the girls the little little ones not the decrepit starving $i$ have no patience anymore but the hundreds of girls in her belly chanting singing along you can see them unfold in the crevices of the beauty baroque fleshies

she leaves her mouth on things

in these folds we have full lips and open mouths the lips are open cherry red desiring the mouths are aching they are together the fold is both the lip and the mouth the inner and outer simultaneously in this we are swallowing and vomiting in one breath we are neither inside nor outside we are both and neither. we approach nothing(ness.

there she is.

dreaming

nothingness.

she leaves her mouth on things

this nothing

ness/

for her.

has

alotof:

skybluey skybluey skybluey skybluey skybluey skybluey skybluey skybluey skybluey skybluey skybluey skybluey skybluey skybluey skybluey skybluey skybluey skybluey skybluey skybluey skybluey skybluey skybluey skybluey skybluey skybluey skybluey skybluey skybluey skybluey skybluey skybluey skybluey skybluey skybluey skybluey skybluey skybluey skybluey skybluey 
skybluey skybluey skybluey skybluey skybluey skybluey skybluey skybluey skybluey skybluey skybluey skybluey skybluey skybluey skybluey skybluey skybluey skybluey skybluey skybluey skybluey skybluey skybluey skybluey skybluey skybluey skybluey skybluey skybluey skybluey skybluey skybluey skybluey skybluey skybluey skybluey skybluey skybluey skybluey skybluey skybluey skybluey skybluey skybluey skybluey skybluey skybluey skybluey skybluey skybluey skybluey skybluey skybluey skybluey skybluey skybluey skybluey skybluey skybluey skybluey skybluey skybluey skybluey skybluey skybluey skybluey skybluey skybluey skybluey skybluey skybluey skybluey skybluey skybluey skybluey skybluey skybluey skybluey skybluey skybluey

and,

there she is.

dreaming of a beautiful nothingness

where she leaves her mouth up/on $\mathrm{n}$ o $\mathrm{t} \mathrm{h}$ in $\mathrm{g} \mathrm{n}$ e s s approaching oblivion resisting annihilation. 